\section{Birlesik Dünya Arastrma Cypriot Journal of Educational \\ BD-CENTER \\ Sciences}

Innovasyon ve Yayınalık Merkezi
Volume 15, Issue 6, (2020) 1464-1479

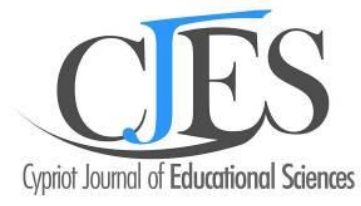

www.cjes.eu

\title{
Investigation of relationship between high school teachers' self- efficacy perceptions and job satisfaction
}

\author{
Battal Göldağ ${ }^{\text {* }}$, İnönü University, Malatya OSB Vocational School, 2.OSB Mahallesi 1.Cad. No:11 Yeşilyurt - \\ MALATYA, Malatya 44280, TURKEY
}

\section{Suggested Citation:}

Göldağ, B. (2020). Investigation of relationship between high school teachers' self- efficacy perceptions and job satisfaction. Cypriot Journal of Educational Science. 15(6), 1464-1479. https://doi.org/10.18844/cjes.v15i6.5285

Received from August 15, 2020; revised from November 1, 2020; accepted from December 15, 2020.

${ }^{\circ} 2020$ Birlesik Dunya Yenilik Arastirma ve Yayincilik Merkezi. All rights reserved.

\begin{abstract}
This research aims to determine the relationship between self-efficacy perceptions and job satisfaction of teachers working in high schools. The universe of the research is composed of the teachers working in high schools in Malatya Battalgazi and Yeşilyurt districts in the fall semester of the academic year 2019-2020. Simple random sampling method has been used for sample selection. In our study, the "Teacher Self-Efficacy Scale" and the short form of the adapted "Minnesota Job Satisfaction Scale" have been used. According to the new results we obtained in our research; teachers' job satisfaction is at a moderate level; self-efficacy perceptions are quite sufficient. There is a moderately significant positive correlation between self-efficacy levels perceived by teachers, self-efficacy levels of student participation, classroom management self-efficacy levels, teaching strategies self-efficacy levels, general job satisfaction levels, internal satisfaction levels and external satisfaction levels.
\end{abstract}

Keywords: Self-efficacy, Teacher Self-Efficacy, Job Satisfaction, High School Teachers;

* ADDRESS FOR CORRESPONDENCE: Battal, GÖLDAĞ, Affiliation, 2.OSB Mahallesi 1.Cad. No:11 Yeşilyurt - MALATYA, Malatya and 44280, TURKEY 


\section{Introduction}

Self-efficacy, which was first introduced in Social Learning Theory, according to Bandura; "their beliefs about their capacity to produce performance levels that have an impact on events that affect people's lives". Self-efficacy beliefs determine how people feel, how they think, how they motivate, act and determine their life choices, their resistance to stress and depression (Bandura, 1994; Bandura, 2006). Perceived self-efficacy; strong self-efficacy beliefs can encourage the onset and persistence of behavior, while weak self-efficacy beliefs can contribute to avoiding behavior (Wood \& Bandura, 1989), and weak self-efficacy beliefs can contribute to avoiding behavior (Haycock, McCarthy \& Skay, 1998). The self-efficacy view has been found out by several factors. Among others, these are experiences (such as failure or success), observational experiences (witnessing the failure and success of other people), persuasion experiences (especially by family, peer groups, his/her colleagues) and emotional experience (living emotions intensely such as, fear, excitement, etc.) (Akkoyunlu \& Orhan, 2003; Cansoy, Parlar \& Kılınç, 2017). There is a need for investigating the relationship among high school teachers' self- efficacy perceptions and job satisfaction using various tools in different regions. Thus, these studies will provide the researchers with various findings and enable them to compare those results and conclude in a decisive result.

\subsection{Teacher Self-Efficacy}

Self-efficacy in the field of education refers to teachers' beliefs about their ability to achieve the desired change in children's success. The belief in one's abilities is the driving force affecting one's motivation to move on (Guo, Dynia, Pelatti \& Adalet, 2014). Based on social cognitive theory, Skaalvik \& Skaalvik (2010) defined teacher self-efficacy as "beliefs of the teacher about their ability to plan, organize and perform the activities required to achieve specific educational goals". According to Gavora (2011), teacher self-efficacy is "teachers' beliefs in their own abilities and skills as educators." Self-efficacy beliefs affect thought patterns and emotions, which activates or blocks actions. Ashton described it as "the belief that teachers have a positive effect on student learning". In general, competence is perceived as teachers' beliefs about how well students can learn (Guskey \& Passaro, 1994).

The self-efficacy perception of teachers includes a range of beliefs about their capacity to teach and have a profound positive impact on student learning. These beliefs are linked to behavioral patterns that create significant differences in the type of teaching of teachers shown in the classroom and the strategies and methods teachers use in their daily practice. (Achurraa \& Villardón, 2012). Teachers' self-efficacy, that is, their belief in their ability to effectively deal with teachers' professional activities, obligations and challenges, plays an important role on affecting important academic characteristics (e.g. student success and motivation) and in the better conditions of the working environment (Barni, Danioni \& Benevene, 2019) also has a significant impact upon the improvement of students' cognitive and affective skills in the learning and teaching process (Akay \& Boz, 2011) and the task of creating learning environments appropriate to the development of cognitive skills that are predominantly based on the skills and self-efficacy of teachers. Teachers with high sense of selfefficacy in teaching abilities could motivate the students and increase their cognitive improvements. Those teachers having a low sense of self-efficacy, on the other hand, initiate an audit-oriented orientation based on heavy sanctions to keep students working (Bandura, 1994).

According to Woo, Ashari, Ismail \& Jumaat (2018), teacher self-efficacy perception is composed of general teaching self-efficacy perception and individual self-efficacy perception. Here general teaching self-efficacy is the belief that the teacher can help students to the extent that the students have the 
ability to learn. Personal self-efficacy is teachers' belief in their ability to make changes in students. This concept is that teachers judge their teaching capacity.

According to Gibbs (2009), at least four self-efficacy tools can be used to explain how teachers teach and their desire to persevere in difficult situations. These are important indicators of the effectiveness of the teacher. The types of self-efficacy of teachers are:

Behavioral self-efficacy: the teacher's belief in the ability to perform certain actions to deal with specific teaching situations.

Cognitive self-efficacy: the teacher's belief in the ability to use control over his own thinking in certain special teaching situations.

Emotional self-efficacy: the teacher's belief in the ability to use control over emotions in certain teaching situations.

Cultural self-efficacy: the teacher's belief in the ability to perform certain actions as a teacher in culturally appropriate ways in certain situations of action. This structure is relatively unexplored.

Teachers' perceptions of self-efficacy affect students in various ways. Rather than teachers having low self-efficacy beliefs; teachers having high self-efficacy beliefs use more effective educational strategies (Caprara, Barbaranelli, Steca, \& Malone, 2006) to apply didactic innovations in the classroom environment, to teach methods that encourage students' autonomy, to take responsibility for children who need special education, to reduce supervised control, and to manage classroom problems. They manage more effectively, show more effort in organizing, planning and delivering their lessons, maintain higher goals in education, and are more open to solidarity and the implementation of new educational practices (Ruble, Usher and McGrew, 2011) also have got higher goals and more positive attitudes about their students (Gibson \& Dembo, 1984). Teachers' belief in their personal activities affects motivating and encouraging learning, the types of learning atmosphere which they create, and the degree of academic improvements achieved by the students (Bandura, 1993), their students' motivation and achievement (Klassen \& Chiu, 2010).

\subsection{Job Satisfactions}

Job satisfaction, the feelings and attitudes of people for their work (Armstrong, 2006), the degree of fulfillment of the individual's job needs, and the state of mind that covers all of the feelings (Evans, 1999), the tendency to evaluate the individual's job, explaining the link between job stimuli and responses (Ilies \& Judge, 2004), the total satisfaction level of employees (Phillips \& Connel, 2003) and the total beliefs and feelings people have got for their present jobs (George \& Jones, 2012). While positive attitudes towards work done show job satisfaction, negative attitudes towards work show dissatisfaction with work done. Job satisfaction degrees or levels of employees may change between extreme satisfaction to extreme dissatisfaction. Emotional responses are responsible for the difference between job satisfaction defined by Balcı (1985) as "the employee's desires (value, importance, purpose, desire), such as the job itself, wages, working conditions, opportunities for promotion and development, and their perceptions about the degree of their employment". 


\subsubsection{Determinants of Job Satisfaction}

According to George and Jones (2012), four factors affect the level of job satisfaction experienced by the person. These are personality, values, working conditions and social impact._The level of job satisfaction is influenced by internal and external factors, audit quality, social relations with the study group, and the level of success and failure in the individual's work. Internal business factors are those such as responsibility, self-management, talent development and observed performance. However, external factors are company policies, auditing, wage satisfaction, external rewards reflected in wages, and the reward system in which workers work and the external environment. Factors affecting job satisfaction; career opportunities are teamwork and work-related problems (Armstrong, 2006; Decker, Harris-Kojetin \& Bercovitz, 2009). According to Phillips \& Connel (2003), job satisfaction includes five factors. These are satisfaction, wages, promotion opportunities, supervision, relations with other employees.

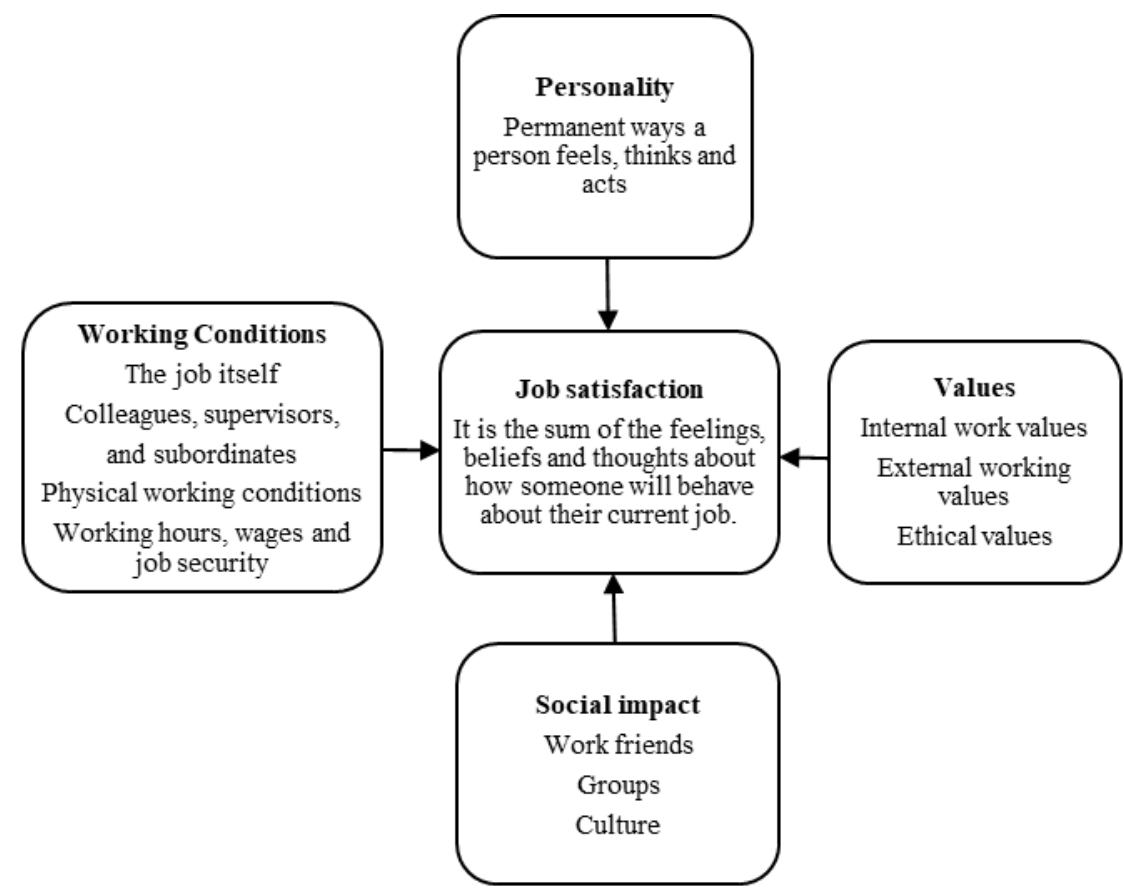

Figure 1. Determinants of Job Satisfaction, George \& Jones (2012)

The self-efficacy beliefs of teachers play an important role in influencing and maintaining their involvement into school and also to job satisfaction (Caprara et al., 2006). Job satisfaction is closely related with high degree of job performance and is a "determining factor" affecting teachers' behavior and performance. While self-efficacy makes a significant contribution to teachers 'job satisfaction (Klassen \& Chiu, 2010), it has been vital for teachers' psychological conditions, feelings for job 
satisfaction, intention to remain in the profession and participation in the profession. (Kuusinen, 2016).

\subsubsection{The purpose of study}

The main aim of the present study is to find out the relationship among the self-efficacy perceptions and job satisfaction of teachers working in high schools. For this aim, answers for the following questions have been searched for;

(1) The level of teachers' perceptions of self-efficacy.

(2) At what level are teachers' perceptions about job satisfaction?

(3) Do teachers' perceptions of self-efficacy and job satisfaction differ in terms of gender, dignity of the teaching profession and school variables in which they work?

(4) Is there a significant relationship between teachers' self-efficacy perceptions and job satisfaction?

\section{Method}

\subsection{Research Model}

In this research, relational screening model, which is one of the quantitative research methods, was used. "Scanning models can be defined as research approaches aiming to define a condition existing in the past or still existing. The subject, it may be an object or an individual, which is the target of the study, can be defined in its own situations and as it is" (Karasar, 2005). The relational screening models are those that aim to determine the presence or degree of co-exchange among two and/or more variables (Cohen, Manion \& Morrison, 2011).

\subsection{Population and Sample}

The population of the research consists of teachers working in high schools in Malatya Battalgazi and Yeşilyurt districts in the spring semester of 2019-2020 academic year. For sample selection, simple random sampling method has been used. Information about teachers is given in Table 1. 46.7\% (85 people) of the teachers participating in the research are women and 53.3\% (97 people) are men. 79.7\% (145 people) are undergraduates, $20.3 \%$ (37 people) are graduates. 39\% (71 people) think that the teaching profession is perceived as a respected profession and $61 \%$ think that it is not perceived as a respected profession. 16.5\% (30 people) work in Science High School, 33.5\% (61 people) in Anatolian High School and 50\% (91 people) work in Vocational High School. 3.8\% (7 people) 26-30, 7.7\% (14 people) 31-35, 17.6\% (32 people) 36-40, 30.2\% (55 people) $41-45$ and $40.7 \%$ (74 people) are aged 46 and over. The job satisfaction level of $48.4 \%$ ( 88 people) is average and $51.6 \%$ (94 people) are high. 
Table 1. Descriptive statistics of Teachers

\begin{tabular}{|c|c|c|c|}
\hline & & Frequency & Percent \\
\hline \multirow[t]{2}{*}{ Gender } & Female & 85 & 46,7 \\
\hline & Male & 97 & 53,3 \\
\hline \multirow[t]{2}{*}{ Education status } & $\begin{array}{l}\text { Undergraduat } \\
\mathrm{e}\end{array}$ & 145 & 79,7 \\
\hline & Graduate & 37 & 20,3 \\
\hline \multirow{2}{*}{$\begin{array}{l}\text { Is the teaching } \\
\text { profession respectable? }\end{array}$} & Yes & 71 & 39,0 \\
\hline & No & 111 & 61,0 \\
\hline \multirow[t]{3}{*}{ School of Duty } & $\begin{array}{l}\text { Science High } \\
\text { School }\end{array}$ & 30 & 16,5 \\
\hline & $\begin{array}{l}\text { Anatolian High } \\
\text { School }\end{array}$ & 61 & 33,5 \\
\hline & $\begin{array}{l}\text { Vocational } \\
\text { High School }\end{array}$ & 91 & 50,0 \\
\hline \multirow[t]{5}{*}{ Age } & $26-30$ & 7 & 3,8 \\
\hline & $31-35$ & 14 & 7,7 \\
\hline & $36-40$ & 32 & 17,6 \\
\hline & $41-45$ & 55 & 30,2 \\
\hline & $46+$ & 74 & 40,7 \\
\hline \multirow[t]{3}{*}{ Satisfaction Level } & Average & 88 & 48,4 \\
\hline & High & 94 & 51,6 \\
\hline & Total & 182 & 100,0 \\
\hline
\end{tabular}

\subsection{Data Collection Tools}

In our study, "Teacher Self-Efficacy Scale" introduced by Tschannen-Moran \& Hoy (2001) and converted into Turkish by Çapa, Çakıroğlu \& Sarıkaya (2005) has been utilized to find out the teachers' self-efficacy perception levels. The scale consists of three factors: ensuring student participation, teaching strategies, and classroom management. Cronbach Alpha internal consistency coefficients of the factors are $.82, .86$ and .84 . The Cronbach Alpha internal consistency coefficient of the entire scale is .93. According to the result we obtained in our research; the Cronbach Alpha internal consistency coefficients of the factors are $.83, .88$ and .89 , respectively. The Cronbach Alpha internal consistency coefficient of the entire scale is .94 .

A short form of the "Minnesota Job Satisfaction Scale" introduced by Weiss, England, David \& Lofguist (1967) and translated into Turkish by Baycan (1985) is used to measure teachers' job satisfaction levels. The short form of the scale consists of two factors: internal satisfaction and external satisfaction. It deals with aspects that have little to do with the job or task itself, such as external satisfaction, paid wages. Internal satisfaction corresponds to the nature of work and how people feel about what they do (Spector, 1997). The overall job satisfaction score is obtained throughout the scale. If the score obtained is 75 and above, it represents a high level of job satisfaction, an average of 26-74 is job satisfaction, and 25 and below represents a low level of job satisfaction (Weiss et al., 1967). According to the result we obtained in our research, the Cronbach 
Alpha internal consistency coefficient for the internal satisfaction factor is 0,86 and the Cronbach Alpha internal consistency coefficient for the external satisfaction factor is 0,82 . The Cronbach Alpha internal consistency coefficient of the entire scale is 0,905.

\subsection{Data Analysis}

Statistical data analysis has been made using the statistical software package SPSS24.0. The normality assumption for difference analysis has been investigated, both the skewness and kurtosis coefficients are found in the range of \pm 1 (George \& Mallery, 2016), and the newly obtained data illustrated normal distribution. For this reason, the obtained data has been tested using the t-test, one-way analysis of variance (ANOVA) for descriptive analyzes (mean and standard deviation) and independent groups with parametric analyzes. Pearson Product Moment Correlation Analysis was used to determine the relationship between teachers' job satisfaction levels and teacher self-efficacy levels. The significance level has been taken as $p<, 05$.

\section{Results}

In this section, findings about teachers' perceived job satisfaction levels, teacher self-efficacy levels, and then the comparison of job satisfaction levels and self-efficacy levels in terms of several variables and the relationship between teachers' job satisfaction levels and teacher self-efficacy levels are given.

\section{Teachers' Perception of Job Satisfaction and Self-Efficacy Levels}

Findings regarding teachers' perceived job satisfaction levels and self-efficacy levels are given in Table 2. According to the findings we obtained in our study, teachers' job satisfaction is medium $(\bar{x}=$ $73,57)$ and self-efficacy perceptions are "quite sufficient" ( $\bar{x}=95.70)$.

Table 2. Perceived Job Satisfaction and Self-Efficacy Levels of Teachers

\begin{tabular}{lccccc}
\hline & N & Minimum & Maximum & Mean & $\begin{array}{c}\text { Std. } \\
\text { Deviation }\end{array}$ \\
\hline General Satisfaction & 182 & 36,00 & 93,00 & 73,57 & 10,62 \\
Self efficiacy & 182 & 69,00 & 119,00 & 95,70 & 10,15 \\
\hline
\end{tabular}

\section{Do Teachers' Perceived Self-Efficacy Levels and Job Satisfaction Differ by Gender?}

The findings regarding whether the teachers perceived self-efficacy levels and job satisfaction levels differ in terms of gender are given in Table 3. According to Table 3, the internal satisfaction levels $\left(t_{(180)}=2,889, p<0.05\right)$, external satisfaction levels $\left(t_{(180)}=2,223, p<0.05\right)$ and general satisfaction levels of the male and female teachers participating in the research, a statistically significant difference has been found in favor of female teachers between $\left(t{ }_{(180)}=2,762, p<0.05\right)$. The job satisfaction levels perceived by female teachers are higher than male teachers. Total self-efficacy levels perceived by female and male teachers $\left(t_{(180)}=2.717, p<0.05\right)$, self-efficacy levels $\left(t{ }_{(180)}=2.674\right.$, $p<0.05$ ) and classroom management self-efficacy levels, there is a significant difference between ( $t$ $(180)=2.710, p<0.05$ ), but no significant difference is found in instructional strategies self-efficacy $(\mathrm{t}$ $(180)=1.922, p>0.05)$. In terms of those differences, this difference is in favor of female teachers. Selfefficacy levels perceived by female teachers are higher than those of male teachers. 
Table 3. t Test Analysis Results of Teachers' Perceived Job Satisfaction Level and Self-Efficacy Levels by Gender

\begin{tabular}{llllllll}
\hline & Gender & $\mathrm{n}$ & $\bar{x}$ & $\mathrm{~S}$ & $\mathrm{Sd}$ & $\mathrm{t}$ & $\mathrm{p}$ \\
\hline \multirow{2}{*}{ Inner Satisfaction } & Female & 85 & 28,20 & 4,42 & 180 & 2,889 &, 004 \\
& Male & 97 & 26,57 & 5,41 & & & \\
External Satisfaction & Female & 85 & 75,85 & 9,15 & 180 & 2,223 &, 027 \\
& Male & 97 & 71,57 & 11,40 & & & \\
General Satisfaction & Female & 85 & 31,51 & 3,40 & 180 & 2,762 &, 006 \\
& Male & 97 & 30,09 & 3,74 & & & \\
Ensuring Student Participation & Female & 85 & 33,30 & 3,49 & 180 & 2,674 &, 008 \\
& Male & 97 & 31,80 & 3,92 & & & \\
Class management & Female & 85 & 33,01 & 3,57 & 180 & 2,710 &, 007 \\
& Male & 97 & 31,94 & 3,85 & & & \\
Instructional Strategies & Female & 85 & 33,01 & 3,57 & 180 & 1,922 &, 056 \\
& Male & 97 & 31,94 & 3,85 & & & \\
Total Self-efficacy & Female & 85 & 97,83 & 9,16 & 180 & 2,717 &, 007 \\
& Male & 97 & 93,84 & 10,63 & & & \\
\hline
\end{tabular}

\section{Do Teachers' Perceived Self-Efficacy Levels and Job Satisfaction Differ According to Perceived Dignity of the Teacher Profession?}

Those findings about whether the teachers perceived self-efficacy levels and job satisfaction levels differed in terms of the perception and non-perception of the teaching profession as a respected profession are given in Table 4. According to Table 4, internal satisfaction levels $(\mathrm{t}$ (180) $=$ $3,937, p<0,05)$, external satisfaction levels $(t(180)=4,627, p<0,05)$ of teachers who think and do not think that the teaching profession is perceived as a respected profession and overall satisfaction levels $\left(t{ }_{(180)}=4,600, p<0.05\right)$, a significant difference has been found in favor of teachers who thought that the teaching profession was perceived as a respected profession. Teachers who think that teaching profession is perceived as a respected profession have higher job satisfaction levels, teaching strategies perceived by teachers who think and do not think that the teaching profession is perceived as a respected profession self-efficacy levels are $\left(t_{(180)}=2.290, p<0.05\right)$, total self-efficacy levels $\left(t_{(180)}\right.$ $=2.077, \mathrm{p}<0.05)$. There has been a significant difference in favor of teachers who thought that the teaching profession was perceived as a respected profession. There was no significant difference between ensuring student participation levels $(\mathrm{t}(180)=1.696, \mathrm{p}>0.05)$ and classroom management self-efficacy levels $(t(180)=1.569, p>0.05)$.

Table 4. $t$ Test Analysis Results According to Teachers' Reputation Levels of Job Satisfaction and SelfEfficacy Levels Profession Perceived by Teachers

\begin{tabular}{llllllll}
\hline \multirow{2}{*}{ profession } & A respected & $\mathrm{n}$ & $\bar{x}$ & $\mathrm{~S}$ & $\mathrm{Sd}$ & $\mathrm{t}$ & $\mathrm{p}$ \\
\hline \multirow{2}{*}{ Inner Satisfaction } & Yes & 71 & 48,49 & 4,80 & 180 & 3,937 &, 000 \\
& No & 111 & 44,80 & 6,89 & & & \\
External Satisfaction & Yes & 71 & 29,38 & 4,23 & 180 & 4,627 &, 000 \\
& No & 111 & 26,02 & 5,07 & & & \\
General Satisfaction & Yes & 71 & 77,87 & 8,31 & 180 & 4,600 &, 000 \\
Ensuring Student Participation & No & 111 & 70,82 & 11,05 & & & \multirow{2}{*}{092} \\
\hline
\end{tabular}




\begin{tabular}{llllllll}
\hline & No & 111 & 30,40 & 3,83 & & & \\
Class management & Yes & 71 & 33,01 & 2,92 & 180 & 1,569 &, 18 \\
& No & 111 & 32,18 & 4,23 & & & \\
\multirow{3}{*}{ Instructional Strategies } & Yes & 71 & 33,18 & 3,01 & 180 & 2,290 &, 023 \\
\multirow{2}{*}{ Total Self-efficacy } & No & 111 & 31,97 & 4,09 & & & \multirow{2}{*}{039} \\
& Yes & 71 & 97,50 & 7,88 & 180 & 2,077 & \\
\hline
\end{tabular}

\section{Do the Self-Efficacy Levels and Job Satisfaction Levels Perceived by the Teachers Differ According to the Type of School Worked?}

The findings regarding whether the perceived self-efficacy levels and job satisfaction levels of the teachers involving to the study show difference in terms of the type of school served are given in Table 5. According to Table 5, the external satisfaction levels $\left(F_{(2 ; 179)}=1,012, p>0.05\right)$, internal satisfaction levels $\left.\left(F_{(2 ; 179)}\right)=, 139, p>0,05\right)$ and no statistically significant differences are found between general satisfaction levels $\left(F_{(2 ; 179)}=, 184, p>0.05\right)$.

Table 5. Anova Analysis Results of Teachers' Perceived Job Satisfaction Levels and Self-Efficacy Levels According to the School Served.

A: Science High School B: Anatolian High School C: Vocational High School

\begin{tabular}{|c|c|c|c|c|c|c|c|}
\hline & & $\begin{array}{l}\text { Sum of } \\
\text { squares }\end{array}$ & Sd & $\begin{array}{l}\text { Average of } \\
\text { squares }\end{array}$ & $\mathrm{F}$ & $\mathrm{p}$ & $\begin{array}{l}\text { Differ } \\
\text { ence }\end{array}$ \\
\hline \multirow{3}{*}{ Inner Satisfaction } & $\begin{array}{l}\text { Among } \\
\text { groups }\end{array}$ & 83,210 & 2 & 41,605 & 1,012 & ,366 & \\
\hline & In groups & 7358,152 & 179 & 41,107 & & & \\
\hline & Total & 7441,363 & 181 & & & & \\
\hline \multirow{3}{*}{ External Satisfaction } & $\begin{array}{l}\text { Among } \\
\text { groups }\end{array}$ & 7,097 & 2 & 3,549 & 139 & 870 & \\
\hline & $\begin{array}{l}\text { groups } \\
\text { In groups }\end{array}$ & 4573,458 & 179 & 25.550 & & & \\
\hline & Total & 4580,555 & 181 & & & & \\
\hline \multirow{4}{*}{ General Satisfaction } & Among & 41,937 & 2 & 20,968 & 184 & ,832 & \\
\hline & groups & & & & & & \\
\hline & In groups & 20388,486 & 179 & 113,902 & & & \\
\hline & Total & 20430,423 & 181 & & & & \\
\hline \multirow[b]{2}{*}{ Ensuring Student } & Among & 102,358 & 2 & 51,179 & 3,974 & 020 & $A, B>C$ \\
\hline & groups & & & & & & \\
\hline \multirow{2}{*}{ Participation } & In groups & 2305,005 & 179 & 12,877 & & & \\
\hline & Total & 2407,363 & 181 & & & & \\
\hline \multirow{4}{*}{$\begin{array}{l}\text { Classroom } \\
\text { Management }\end{array}$} & Among & 26,981 & 2 & 13,490 & 936 & ,394 & \\
\hline & groups & & & & & & \\
\hline & In groups & 2578,514 & 179 & 14,405 & & & \\
\hline & Total & 2605,495 & 181 & & & & \\
\hline \multirow{3}{*}{ Instructional Strategies } & Among & 113,009 & 2 & 56,504 & 4,156 & ,017 & $A, B>C$ \\
\hline & groups & & & 12597 & & & \\
\hline & Total & 2546,951 & 181 & & & & \\
\hline \multirow{4}{*}{ Total Self-efficacy } & Among & 668,768 & 2 & 334,384 & 3,329 & ,038 & $A, B>C$ \\
\hline & groups & & & & & & \\
\hline & In groups & 17978,798 & 179 & 100,440 & & & \\
\hline & Total & 18647,566 & 181 & & & & \\
\hline
\end{tabular}


A significant difference is not found between the classroom management self-efficacy levels $\left(F_{(2 ; 179)}=\right.$, 936, $p>0.05$ ) according to the schools they work in. Self-efficacy levels to ensure student participation $\left(F_{(2 ; 179)}=3.974, p<0.05\right)$, teaching strategies self-efficacy levels $\left(F_{(2 ; 179)}=4.156, p<0.05\right)$ and total selfefficacy levels, a significant difference was found $\left(F_{(2 ; 179)}=3.329, p<0.05\right)$. In terms of the results of the Tukey test, this difference between the self-efficacy levels of student participation was found in the Science High School ( $\bar{x}=31.63)$ and Anatolian high school $(\bar{x}=31.44)$ and teachers working in the Vocational High School $(\bar{x}=30.75)$ are among the teachers. The difference between teaching strategies self-efficacy levels is between teachers working in Science High School $(\bar{x}=33.60)$ and Anatolian high school $(\bar{x}=33.01)$ and teachers working in Vocational High School $(\bar{x}=31.68)$. The difference between the total self-efficacy levels is between the teachers working in Science High School $(\bar{x}=98.30)$ and Anatolian high school ( $\bar{x}=97.24)$ and teachers working in Vocational High School $(\bar{x}=93.82)$.

\section{Is there a significant relationship between teachers' perceptions of self-efficacy and job satisfaction?}

The findings regarding the relationship between the self-efficacy levels and job satisfaction levels perceived by the teachers participating in the research are given in Table 6 . In view of the Table 6, there is a moderately significant positive relationship between self-efficacy levels perceived by teachers and general job satisfaction levels $(r=, 377, p<, 01)$ internal satisfaction levels $(r=, 394, p<$, $01)$ and external satisfaction levels $(r=, 294, p<, 01)$. There is a moderately significant positive relationship between student self-efficacy level and internal satisfaction levels $(r=, 398, p<, 01)$, external satisfaction levels $(r=, 340, p<, 01)$ and general satisfaction levels $(r=, 398, p<, 01)$. There is a moderately positive relationship between classroom management self-efficacy level and internal satisfaction levels $(r=, 308, p<, 01)$, external satisfaction levels $(r=, 184, p<, 05)$ and general satisfaction levels $(r=, 373, p<, 01)$. There is a moderately positive relationship between teaching strategies self-efficacy and internal satisfaction levels $(r=, 355, p<, 01)$, external satisfaction levels $(r$ $=, 280, p<, 01)$ and general satisfaction levels $(r=, 398, p<, 01)$.

Table 6. Results obtained for Pearson Product Moment Correlation Analysis for Determining the

Relationship Between Teachers' Perceived Self-Efficacy Levels and Job Satisfaction Levels.

\begin{tabular}{lccc}
\hline & $\begin{array}{c}\text { Inner } \\
\text { Satisfaction }\end{array}$ & $\begin{array}{c}\text { External } \\
\text { Satisfaction }\end{array}$ & $\begin{array}{c}\text { General } \\
\text { Satisfaction }\end{array}$ \\
\hline Ensuring Student Participation &, $398^{* *}$ &, $340^{* *}$ &, $401^{* *}$ \\
Classroom Management &, $308^{* *}$ &, $184^{*}$ &, $273^{* *}$ \\
Instructional Strategies &, $369^{* *}$ &, $280^{* *}$ &, $355^{* *}$ \\
Self-efficacy &, $394^{* *}$ &, $294^{* *}$ &, $377^{* *}$ \\
\hline
\end{tabular}

*. $p<0,05, * * . p<0,01$

\section{Discussion}

According to the results we obtained in our research, teachers' job satisfaction is at a medium level. Bayhan (2009), Kumaş \& Deniz (2010), Buluç \& Demir (2015), Karademir (2016), Büyükgöze \& Özdemir (2017), Aslan \& Kalkan (2018) have found that the general job satisfaction of teachers is moderate, similar to the results we found in our study. According to the result we obtained in our research, the self-efficacy perceptions of the teachers participating in the research are quite sufficient. In their study, Gençtürk \& Memiş (2010) concluded that the teachers' self-efficacy perceptions of 
teacher candidates were quite adequate, while Buluç \& Demir (2015) concluded that their self-efficacy perceptions were at a sufficient level.

According to the results we obtained in our study, the internal satisfaction, external satisfaction and general job satisfaction levels perceived by female teachers are higher than those of male teachers. The results obtained in those studies conducted show the differences. It was concluded that Demirtaş (2010), Ozdem \& Sezer (2019) did not differ in their findings. Kumaş \& Deniz (2010), Gençtürk \& Memiş (2010), Shaukat, Vishnumolakala \& Bustami (2019) concluded that female teachers have higher job satisfaction than male teachers. Crossman \& Harris (2006), Seifert \& Umbach (2008), Sabharwal \& Corley (2009), Sadeghi, Zaidato, Habibah \& Foo (2012), Tran (2015), Akbulut (2015) concluded that female teachers are more likely than male teachers in this respect.

According to the result we obtained in our research, the self-efficacy levels perceived by female teachers are higher than male teachers. Kurt, Güngör \& Ekici (2014), Shaukat, Vishnumolakala \& Bustami (2019) support the results we obtained in our work. Akay \& Boz (2011) and Elkatmış (2018) concluded that there was no difference in this respect their study, while Tran (2015) concluded that the self-efficacy levels of male teachers are higher than women. According to the result we obtained in our research; the teachers who think that the teaching profession is perceived as a respectable profession have higher levels of internal satisfaction, external satisfaction and general job satisfaction levels than the teachers who think that the teaching profession is not perceived as a respected profession.

The teaching strategies perceived by the teachers who think that the teaching profession is perceived as a respected profession, self-efficacy levels, total self-efficacy levels are higher than the teachers who think that the profession is not perceived as a respected profession. Self-efficacy levels and classroom management self-efficacy levels are the same. According to the result we obtained in our research; the external satisfaction levels, internal satisfaction levels and general satisfaction levels of the teachers participating in the research are the same according to the schools they work in. It was concluded that the classroom management self-efficacy levels were the same according to the schools in which the teachers participated in the research. The self-efficacy levels, teaching strategies, selfefficacy levels and total self-efficacy levels of teachers working in science and Anatolian high schools are higher than the teachers working in Vocational High Schools.

According to the results we obtained in our study, teachers' self-efficacy perceptions are quite enough. In our study, it was concluded that there has been a moderately significant relationship between teachers' perceptions of teaching self-efficacy and job satisfaction levels. When the studies conducted are examined, it is seen that many studies support our results (Randhawa, 2003; Caprara et al., 2006; Ruma, Houchins, Jolivette \& Benson, 2010; Klassen \& Chiu, 2010; Skaalvik \& Skaalvik, 2010; Telef, 2011; Karabıyık \& Guardaz, 2014; Buluç \& Demir, 2015; Kuusinen, 2016; Blackburn, Bunch \& Chris Haynes, 2017; Türkoğlu, Cansoy \& Parlar, 2017; Saracaloğlu, Aldan Karademir, Dinçer \& Dedebali, 2017; Carswell, 2018; Demir, 2020) can be given as examples. Similar results are achieved in studies conducted between different professional groups. In his study with nurses, Baysal (2010), in his study with Machmud (2018) local government institutions, Law \& Guo (2016) concluded that there was a positive relationship between employees' self-efficacy perceptions and job satisfaction. There is also a positive relationship between teachers' teaching performance and job satisfaction. (Kadtong, Unos, Antok \& Midzid, 2017). According to these results, as teachers' self-efficacy perceptions increase, their job satisfaction levels also increase. According to Bandura (1994), teachers with high self-efficacy perception prepare environments that will improve students' cognitive skills, they strive to learn, and motivate them to reach their goals. Therefore, the high self-efficacy perceptions of the teachers will 
contribute to the increase in student success and to develop positive attitudes towards the school and the class. Increasing student success will increase job satisfaction for teachers. Because the aim of a teacher is to explain the lesson in the best way and to raise successful students. Teachers state that job satisfaction is gained from the nature of daily classroom activities, working with children, seeing the progress of children, working with supporting colleagues and the general school climate influences this (Klassen \& Chiu, 2010).

\section{Conclusion}

As a conclusion, we can state the following results. The majority of teachers think that the teaching profession is not perceived as a respected profession by the society. The fact that their work is not neglected by the society affects teachers' job satisfaction negatively. In addition, according to the result we obtained in our study regarding job satisfaction; the lowest averages were obtained in terms of the availability of promotion $(\bar{x}=2.84)$ and the wage they received in return for their work $(\bar{x}=2.86)$. According to the "Education at a glance" report of the Economic Cooperation and Development Organization (OECD), published in September; teaching is not seen as an attractive profession because of salaries in Turkey. Despite the increase in education spending in Turkey, teachers at all levels of education from pre-school to high school are paid a fixed salary. According to the OECD averages, the annual salaries of teachers at the beginning of the task differ according to the level of duty (pre-school; $\$ 31,276$, secondary education, general programs; $\$ 35,859$ ). In Turkey, the salary of starting a new teacher-year $\$ 25955$, while the top teacher salary is $\$ 32953$ came to seniority annually. This difference is $27 \%$ higher than the starting salary. However, the difference is between $85-90 \%$ in OECD averages (OECD, 2019).

In this regard, it is necessary to take and implement decisions that will increase the dignity of the teaching profession of the Ministry of National Education - for example, increasing salaries, providing promotion opportunities, keeping preference points high when selecting students. People with strong self-efficacy beliefs tend to be more satisfied with their jobs, show more commitment to their work (Trentham, Silvern \& Brogdon, 1985), and teachers' self-efficacy beliefs play an important role in influencing and maintaining their school loyalty and job satisfaction (Caprara at al. , 2006). Teachers with high self-efficacy experience higher levels of job satisfaction and lower levels of work-related stress. (Caprara et al., 2003 as cited in Barni, Danioni \& Benevene, 2019). In terms of their profession, teachers who do not have job satisfaction exhibit low participation and are at risk of leaving the profession (Klassen and Chiu, 2010). In the training programs of faculties that train teachers and provide pedagogic formation training, teachers with strong self-efficacy beliefs should be trained, and various courses, seminars and in-service training should be provided to raise their self-efficacy perceptions. Having teachers' strong self-efficacy beliefs will contribute to the increasing job satisfaction.

\section{Recommendations}

We suggest that future studies can be conducted on the investigation of the relationship between high school teachers' self- efficacy perceptions and job satisfaction using different and various tools. We also suggest that new researchers conduct similar studies in their own regions and compare their results with the results of this study. The last but not least, we hope and suggest that the findings of the present study are going to shed light on the issue and guide prospective researchers in the area. 
Göldağ, B. (2020). Investigation of relationship between high school teachers' self- efficacy perceptions and job satisfaction. Cypriot Journal of Educational Science. 15(6), 1464-1479. https://doi.org/10.18844/cjes.v15i6.5285

\section{References}

Achurraa, C., \& Villardón, L. (2012). Teacher' Self-Efficacy and Student Learning. The European Journal of Social \& Behavioural Sciences, 366-383, 2(2). https://doi.org/10.15405/FutureAcademy/ejsbs(2301-2218).2012.2.17

Akay, H. \& Boz, N. (2011). Examining the Relationships among Prospective Primary School Teachers' Attitude towards Mathematics, Mathematics Self-Efficacy Beliefs, Teacher Self-Efficacy Beliefs. The Journal of Turkish Educational Sciences, 9(2), 281-312.

Akbulut, B. (2015). The Relationship between the Upper Secondary School Teachers' Organizational Image Perceptions and Job Satisfaction Levels [Unpublished doctoral dissertation]. University of Hacettepe. https://tez.yok.gov.tr/UlusalTezMerkezi/

Akkoyunlu, B., \& Orhan, F. (2003). Bilgisayar ve öğretim teknolojileri eğitimi (BÖTE) bölümü öğrencilerinin bilgisayar kullanma öz yeterlik inancı ile demografik özellikleri arasındaki ilişki. The Turkish Online Journal of Educational Technology, 2(3), 86-93.

Armstrong, M. (2006). A Handbook of Human resource Management Practice. Kogan Page Publishing.

Aslan, M. \& Kalkan, H. (2018). Analysis of Self-Efficacy Perceptions of Teachers, Bingöl University Journal of Social Sciences Institute,, 8(16), 477-493. https://doi.org/10.29029/busbed.434926

Balcı, A. (1985). Eğitim yöneticisinin iş doyumu (Job satisfaction of the education manager) [Unpublished doctoral dissertation]. University of Ankara. https://www.researchgate.net/publication /331224684_Egitim_Yoneticisinin_Is_Doyumu-Prof_Dr_Ali_Balci-Doktora_Tezi

Bandura, A. (1993). Perceived self-efficacy in cognitive development and functioning. Educational Psychologist, 28(2), 117-148.

Bandura, A. (1994). Self-efficacy. (V. S. Ramachaudran, Ed.), Encyclopedia of human behavior. Academic Press.

Bandura, A. (2006). Guide for constructing self-efficacy scales (F. Pajares and T. Urdan, Ed.), Adolescence and education: (5) Self efficacy and adolescence (307-337). Information Age.

Baycan, A. (1985). An Analysis of Several Aspects of Job Satisfaction between Different Occupational Groups [Unpublished master thesis]. University of Bogazici. https://tez.yok.gov.tr/UlusalTezMerkezi/

Bayhan, P. (2009). The relation between primary education first stage form teachers? Job satisfaction and their attitudes toward teaching profession [Unpublished master thesis]. University of Yeditepe https://tez.yok.gov.tr/UlusalTezMerkezi/

Baysal, E. (2010). Nurses self-efficacy beliefs and job satisfaction relationship: A field study at the University Hospital [Unpublished master thesis] University of İstanbul. https://tez.yok.gov.tr/UlusalTezMerkezi/

Barni, D., Danioni, F. \& Benevene, P. (2019). Teachers' Self-Efficacy: The Role of Personal Values and Motivations for Teaching. Frontiers in Psychology, 10, 1-7. https://doi.org/10.3389/fpsyg.2019.01645

Blackburn, J.J., Bunch, J.C. \& Chris Haynes, J. (2017). Assessing the Relationship of Teacher Self-Efficacy, Job Satisfaction, and Perception of Work-Life Balance of Louisiana Agriculture Teachers. Journal of Agricultural Education, 58(1), 14-35. https://doi.org/10.5032/jae.2017.01014

Buluç, B. \& Demir, S. (2015). The Relationship between Job Satisfaction and Self Efficacy based on Elementary and Middle School Teacher's Perceptions. Ahi Evran University Journal of Kırşehir Faculty of Education, 16(1), 289-308.

Büyükgöze, H., \& Özdemir, M. (2017). Examining Job Satisfaction and Teacher Performance within Affective Events Theory. Inonu University Journal of the Faculty of Education, 18(1), 311-325. https://doi.org/10.17679/inuefd.307041 
Cansoy, R., Parlar, H. \& Kılınç, A.Ç. (2017). Teacher Self-Efficacy as a Predictor of Burnout. International Online Journal of Educational Sciences, 9 (1), 141 - 155. https://doi.org/10.15345/iojes.2017.01.011

Caprara, G. V., Barbaranelli, C., Steca, P. and Malone, P.S. (2006). Teachers' self-efficacy beliefs as determinants of job satisfaction and students' academic achievement: A study at the school level. Journal of School Psychology. 44, 473-490. https://doi.org/10.1016/j.jsp.2006.09.001

Carswell, A.J.A (2018). Job Satisfaction and Self-Efficacy Score Differences in General and Special Education Teachers as Measured By the Job Satisfaction Survey and Teachers' Sense of Efficacy Scale [Unpublished doctoral dissertation]. University of Liberty. https://pdfs.semanticscholar.org/9e3e/2d424de97097009cccc 232006785e6b74848.pdf

Cohen, L., Manion, L. \& Morrison, K. (2011). Research methods in education. 7th ed. Routledge.

Crossman, A. \& Harris, P. (2006). Job Satisfaction of Secondary School Teachers. Educational Management Administration and Leadership, 34, 29-46. https://doi.org/10.1177/1741143206059538.

Çapa, Y., Çakıroğlu, J. \& Sarıkaya, H., (2005). The Developmeıt and Validation of a Turkish Version of the Teachers' Sense of Efficacy Scale. Education and Science, 30(137),74-81.

Decker, F.H., Harris-Kojetin, L.D. \& Bercovitz, A. (2009). Intrinsic Job Satisfaction, Overall Satisfaction, and Intention to Leave the Job Among Nursing Assistants in Nursing Homes. The Gerontologist, 49(5), 596-610, https://doi.org/10.1093/geront/gnp051

Demir, S. (2020). The role of self-efficacy in job satisfaction, organizational commitment, motivation and job involvement. Eurasian Journal of Educational Research, 85, 205-224, https://doi.org/10.14689/ejer.2020.85.10.

Demirtaş, Z. (2010). Teachers' job satisfaction levels. Procedia Social and Behavioral Sciences, 9, 1069-1073.

Elkatmış, M. (2018). Comparison of Pre-service Teachers and Teachers' Self-efficacy Beliefs. Hacettepe University Journal of Education, 33(2): 402-416. https://doi.org/10.16986/HUJE.2017034373

Evans, L.(1999). Managing to motivate: a guide for school leaders. Cassel

Gavora, P. (2011). Measuring the self-efficacy of in-service teachers in Slovakia. Orbis Scholae, 5(2), 79-94.

Gençtürk, A. \& Memiş, A. (2010). An Investigation of Primary School Teachers' Teacher Efficacy and Job Satisfaction in Terms of Demographic Factors. Elementary Education Online, 9(3), 1037-1054.

George, J.M. \& Jones, G.R. (2012). Understanding and Managing Organizational Behavior, Sixth Edition, New Jersey.

Gibbs, C. (2003). Explaining effective teaching: self-efficacy and thought control of action. Journal of Educational Enquiry, 4(2), 1-14.

Gibson, S., \& Dembo, M. H. (1984). Teacher efficacy: A construct validation. Journal of Educational Psychology, 76(4), 569-582. https://doi.org/10.1037/0022-0663.76.4.569.

Guo, Y., Dynia, J.M., Pelatti, C.Y., \& Justice, L.M. (2014). Self-efficacy of early childhood special education teachers: Links to classroom quality and children's learning for children with language impairment. Teaching and Teacher Education, 39, 12-2. https://doi.org/10.1016/j.tate.2013.11.005.

Guskey, T.R. \& Passaro, P.D. (1994). Teacher Efficacy: A Study of Construct Dimensions. American Educational Research Journal, 31(3), 627-643.

Haycock, L.A., McCarthy, P. \& Skay, C.L. (1998). Procrastination in College Students: The Role of Self-Efficacy and Anxiety. Journal of Counseling \& Development, 76, 317-324. 
Ilies, R. \& Judge, T.A. (2004) An experience-sampling measure of job satisfaction and its relationships with affectivity, mood at work, job beliefs, and general job satisfaction, European Journal of Work and Organizational Psychology, 13(3), 367-389, https://doi.org/10.1080/13594320444000137.

Kadtong, M.L., Unos, M.A., Antok, T.D. \& Midzid, M.A.E. (2017) Teaching Performance and Job Satisfaction among Teachers at Region XII. Proceedings Journal of Education, Psychology and Social Science Research. 4(1), 113-122. https://doi.org/10.21016/4.17.113122.1330.

Karabıyık, B. \& Korumaz, M. (2014) Relationship Between Teachers'Self-Efficacy Perceptions and Job Satisfaction Level. Procedia - Social and Behavioral Sciences 116, 826 - 830. https://doi.org/10.1016/j.sbspro.2014.01.305

Karademir, N. (2016). An Analysis for the Job Satisfaction Levels of the Geography Teachers. Sakarya University Journal of Education, 6/2, 108-122. https://doi.org/10.19126/suje.05343

Karasar, N. (2005). Bilimsel Araştırma Yöntemi. Nobel Basımevi.

Klassen, R.M. \& Chiu, M. M. (2010), Effects on teachers' self-efficacy and job satisfaction: Teacher gender years of experience and job stress, Journal of Educational Psychology, 102(3), 741-756.

Kuusinen, C.M. (2016). The Meaning and Measure of Teacher Self-Efficacy for Effective Classroom Teaching Practices [Unpublished doctoral dissertation]. University of Michigan. https://deepblue.lib.umich.edu/ handle/2027.42/ 133219

Kurt, Güngör \& Ekici (2014). The relationship among teacher efficacy, efficacy regarding teaching, and responsibility for student achievement. Procedia - Social and Behavioral Sciences. 116, 802 - 807, https://doi.org/10.1016/j.sbspro.2014.01.301.

Kumaş, V., \& Deniz, L. (2010). An Investigaton about Job Satisfaction of Teachers. Marmara University Atatürk Education Faculty Journal of Educational Sciences, 32, 123-139.

Law, F.M. \& Guo, G.J.(2016) Correlation of Hope and Self-Efficacy With Job Satisfaction, Job Stress, and Organizational Commitment for Correctional Officers in the Taiwan Prison System. International Journal of Offender Therapy and Comparative Criminology, 60(11) 1257-1277. https://doi.org/10.1177/0306624X15574997

Machmud, S.(2018). The Influence of Self-Efficacy on Satisfaction and Work-Related Performance. International Journal of Management Science and Business Administration. 4(4). 43-47. https://doi.org/10.18775/ijmsba.1849-5664-5419.2014.44.1005

OECD (2019), Education at a Glance 2019: OECD indicators. OECD Publishing, https://doi.org/10.1787/f8d7880den.

Ozdem, G. \& Sezer, S. (2019). The Relationship between Solution-Focused School Leadership and Organizational Cynicism, Organizational Commitment and Teachers' Job Satisfaction. International Journal of Progressive Education, 15(1), 167-183. https://doi.org/10.29329/ijpe.2019.184.11

Phillips, J.J., \& Connel, A.O. (2003). Managing employee retention: a strategic accountability approach. USA: Butterworth-Heinemann.

Randhawa, G. (2003). Relationship of Self-Efficacy with Job Satisfication. The Businnes Review, 10(1). 57-61.

Ruble, L.A., Usher, E.L. \& McGrew, J.H. (2011). Preliminary investigation of the sources of self-efficacy among teachers of students with autism, Focus Autism and other Developmental Disabilities, 26(2), 67-74. https://doi.org/10.1177/1088357610397345.

Ruma, K.V, Houchins, D., Jolivette, K. \& Benson, G (2010). Efficacy Beliefs of Special Educators: The Relationships Among Collective Efficacy, Teacher Self-Efficacy, and Job Satisfaction. Teacher Education and Special Education. 33(3) 225-233. 
Sabharwa, M. \& Corley, E.A. (2009). Faculty job satisfaction across gender and discipline. The Social Science Journal. 46(3), 539-556. https://doi.org/10.1016/j.soscij.2009.04.015

Sadeghi, A., Zaidatol, A.L.P., Habibah, E. \& Foo S.F.(2012). Demographic Analysis on Academic Staff's Job Satisfaction in Malaysian Research Universities. Pertanika Journal of Social Sciences and Humanities. 20(5):1-20.

Saracaloğlu, A.S., Aldan Karademir, Ç., Dinçer, B. \& Dedebali, N.C., (2017). Determining Teaching Styles, SelfEfficacy Believes and Job Satisfaction of Teachers, Education Sciences, (12(1):58-85, https://doi.org/10.12739/NWSA.2017.12.1.1C0669.

Seifert, T.A. \& Umbach, P.D. (2008). The effects of faculty demographic characteristics and disciplinary context on dimensions of job satisfaction. Research in Higher Education. 49(4):357-381. https://doi.org/10.1007/s11162-007-9084-1

Shaukat, S., Vishnumolakala, V.R. \& Bustami, G.A (2019). The impact of teachers' characteristics on their selfefficacy and job satisfaction: a perspective from teachers engaging students with disabilities. Journal of Research in Special Educational Needs, 19(1), 68-76, https://doi.org/10.1111/1471-3802.12425

Skaalvik, E.M. \& Skaalvik, S. (2010). Teacher self-efficacy and teacher burnout: A study of relations, Teaching and Teacher Education, 26(4). 1059-1069. https://doi.org/10.1016/j.tate.2009.11.001

Spector, P. E. (1997). Job Satisfaction: Application, Asssessment, Cause And Consequencs, Sage Publications.

Telef, B.B. (2011). The Study of Teachers' Self-Efficacy, Job Satisfaction, Life Satisfaction and Burnout. Elementary Education Online, 10(1), 91-108.

Tran, V.T. (2015). Effects of Gender on Teachers' Perceptions of School Environment, Teaching Efficacy, Stress and Job Satisfaction. International Journal of Higher Education, 4(4), 147-150.

Trentham, L., Silvern, S. \& Brogolon, R. (1985). Teacher efficacy and teacher competency ratings. Psychology in Schools. 22(3). 343-352.

Tschannen-Moran, M. \& Hoy, A.W (2001). Teacher efficacy: Capturing and elusive construct. Teaching and Teacher Education, 17, 783-805.

Türkoğlu, Cansoy \& Parlar (2017). Examining Relationship between Teachers' Self-efficacy and Job Satisfaction. Universal Journal of Educational Research, 5(5): 765-772, https://doi.org/10.13189/ujer.2017.050509

Weiss, D. J., Dawis, R. W., England, G. W. \& Lofquist, L. H. (1967). Manual for the Minnesota Satisfaction Quesitionnaire. http://vpr.psych.umn.edu/sites/vpr.dl.umn.edu/files/monograph_xxii__manual_for_the_mn_satisfaction_questionnaire.

Woo, P.S., AShari, Z.M., Ismail, Z.B. \& Jumaat, N.F. (2018, December 4-7). Relationship between Teachers' SelfEfficacy and Instructional Strategies Applied among Secondary School Teachers in Implementing STEM Education [Conference presentation]. IEEE International Conference on Teaching, Assessment, and Learning for Engineering https://www.researchgate.net/publication/330478246 Relationship_ Efficacy_and_Instructional_Strategies_Applied_among_Secondary_School_ Wollongong,Australia. Implementing_STEM_Education.

Wood, R. \& Bandura, A. (1989). Impact of conceptions of ability on self-regulatory mechanisms and complex decision making. Journal of Personality and Social Psychology, 56(3), 407-415. 